\title{
Miten kääntää työyhteisön konfliktit oppimiskokemukseksi työhteisösovittelulla?
}

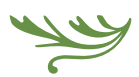

\author{
Vaikka puuttuminen työpaikan konflikteihin on todettu \\ välttämättömäksi työntekijöiden hyvinvoinnille, konfliktien \\ ratkaisumenetelmiä tunnetaan huonosti. Suosiotaan kasvattaneen \\ työyhteisösovittelun uskotaan prosessina kehittävän koko \\ organisaation vuorovaikutustaitoja.
}

KANSALLISET TYÖOLOMITTARIT ovat kertoneet 2010-luvun lopulla karua tarinaa konflikteista työpaikoilla ja tulehtuneista työilmapiireistä (Työolobarometri 2017). Yhteisöissä kohdataan ristiriitoja, asiatonta käytöstä, jopa kiusaamista. Henkilöstöjohtamisen tutkijana olen saanut kuulla, että iso osa esimiesten työstä lohkeaa työyhteisön konfliktien selvittelyyn.

Konfliktit jäävät harvoin vain osapuolten välisiksi. Sen sijaan ne muuttuvat ajan mittaan koko yhteisöä koskeviksi. Huono ilmapiiri saattaa heikentää työntekijän työtehoa ja lisätä sairauspoissaoloja. Työntekijöiden vaihtuvuus voi lisääntyä, ja asioiden selvittely kuormittaa työoloja (Hyvönen \& Koskinen 2010).
Vaikka ratkaisemattomien tai huonosti käsiteltyjen konfliktien tiedetään edistävän ristiriitojen kasvamista, konfliktiratkaisumenetelmiä tunnetaan vähän. Siten esimiehiltä puuttuu välineitä ja osaamista puuttua konflikteihin ja ratkoa niitä kestävällä tavalla (Pehrman 2011).

Kansainvälisesti tunnetun konfliktinratkaisumenetelmän, työyhteisösovitteluun, on havaittu kehittävän koko työyhteisöä ehkäisemään, käsittelemään ja ratkaisemaan konflikteja. (Poitras \& LeTareau 2009; Wall \& Dunne 2012; Saundry ym. 2013).

Suomalaisissa organisaatioissa suosiotaan merkittävästi viime vuosina kasvattanut työyhteisösovittelu on ristiriidan ratkaisemiseen pyrkivä, usein 
JOKA VIIDES SUOMALAINEN

ON JOUTUNUT

\author{
KOHTAAMAAN KIUSAAMISTA \\ TYÖURALLAAN.
}

organisaation ulkopuolisen puolueettoman tahon ohjaama prosessi (Bollen \& Euwema 2013; Järvinen \& Luhtaniemi 2014). Se tarjoaa sekä vaihtoehtoisen tavan että työvälineen kohdata ja ratkoa työyhteisön ristiriitoja.

Työyhteisösovittelun vaikutukset eivät jää pelkästään yksittäiseen konfliktiin, vaan yhteisöllisen prosessin on havaittu parhaimmillaan kehittävän koko työyhteisöä. Itse prosessi, sovittelijan rooli, vuorovaikutteiset menetelmät ja yhteisöllisyys ovat vaikuttaneet siihen, että työyhteisösovittelusta on alettu puhua yhteisöllisen oppimisen prosessina. (Poitras \& LeTareau 2009; Wall \& Dunne 2012; Saundry ym. 2013.) Minkälaista oppimista työyhteisösovittelussa sitten tapahtuu ja miten yhteisöt voivat oppia hyödyntäessään sovittelua?

\section{KONFLIKTIN MÄÄRITTELY}

'Konflikti' on laaja, monisyinen ja tulkinnanvarainen käsite. Yleiskielessä se tarkoittaa yhteentörmäystä, ja käsitteellä viitataankin laajassa mielessä tilanteisiin, joissa ihmisten asenteet, ajatukset ja käytös törmäävät keskenään. (Wall \& Callister 1995). Organisaatiokontekstissa voidaan puhua yksilöiden tai ryhmien välisestä konfliktoitumisesta, jolloin ”taustalla on keskenään vastakkaisia tai ristiriitaisia käsityksiä tilanteen ratkaisemisen päämääristä tai keinoista” (Ikonen-Varila 1994, 67).

Konfliktintutkimuksessa konfliktit luokitellaan niiden luonteen perusteella yleensä tunne- tai asiapohjaisiin. Tunnekonflikteilla viitataan ristiriitoihin ihmissuhteissa, kun taas asiakonflikteissa ongelmat koskevat työn sisältöä tai tavoitteita. Lisäksi voidaan puhua prosessikonflikteista, joilla tarkoitetaan erimielisyyksiä tehtävien suorittamisessa tai vastuissa.
(Jehn 1997.) Konfliktit voidaan jaotella taustan mukaan (Pehrman, 2010):

1) vuorovaikutuksellisiin konflikteihin, jotka syntyvät sanallisen tai sanattoman viestinnän yhteentörmäyksissä,

2) henkilökohtaisista tekijöitä johtuviin konflikteihin, jotka syntyvät sosiaalisissa suhteissa tapahtuneista ongelmista,

3) tehtäväsuuntautuneista syistä johtuviin konflikteihin, kuten erilaisista työtavoista kumpuaviin ongelmiin,

4) kulttuurista johtuviin konflikteihin, jotka taas nousevat erilaisista näkökulmaeroista ja

5) muihin tekijöihin, joita ovat esimerkiksi ailahtelevaisuus ja väärinymmärrykset.

Useissa määritelmissä painottuvat samanaikaiset mutta erisuuntaiset pyrkimykset ja toiveet. Keskeistä konfliktien synnyssä on nimenomaan osapuolten subjektiivinen havainto vallitsevista eroista. Konflikti ei synny vain olemassa olevista näkemyseroista, vaan se vaatii erojen tunnistamisen ja niin sanotun konfliktikynnyksen ylittämisen. Erimielisyyksien ja mielipide-erojen tulee olla tarpeeksi merkityksellisiä ja vakavia, jotta kynnys ylittyy. Konflikti tulkitaankin jatkuvaksi ja kehittyväksi ilmiöksi, jolla on taipumus muuttaa muotoaan. (Rahim 2015.) Sen todetaan olevan erittäin monimutkainen systeemi, jonka taustalla voivat vaikuttaa lukemattomat, joskus jopa toisiinsa liittymättömät syyt (Gallo 2013).

\section{TYÖYHTEISÖN KONFLIKTIT}

Työyhteisökonfliktit voidaan jakaa karkeasti yhteisöllisten ja työperäisten sekä yksilölähtöisten ongelmien aiheuttamiin konflikteihin (Pehrman 2012). Yhteisöllisiin konflikteihin ajaudutaan usein, koska työnjaossa tai vastuualueissa ei ole selviä pelisääntöjä tai tavoitteita ei ole tehty riittävän selviksi. Riittämätön viestintä tai liika kiire voivat aiheuttaa väärinkäsityksiä ja luoda pohjaa konfliktien syttymiselle. Kirjallisuudessa juuri johtamisesta aiheutuvat ristiriidat ovat isoimpia konflikteja aiheuttavia tekijöitä yhteisöissä (Bennet 2013).

Alaiset saattavat kokea johtajan toimintatavat puutteellisiksi, epäoikeudenmukaisiksi tai epäselviksi. 
Taustalla ei kuitenkaan välttämättä ole johtajan toiminta tai muutoksen aiheuttamat epävarmuudet, vaan konflikteille voivat altistaa työn rakenteelliset ongelmat, kuten kilpailuasetelmat tai työnkuvien haasteet. Yksilölähtöiset konfliktit puolestaan kytkeytyvät ongelmiin osaamisessa, arvojen ja näkemyseroissa tai jaksamisongelmissa. Taustalla voi olla myös mielenterveysongelmia. (Vartia ym. 2004.)

Työyhteisöjen epäasiallista käytöstä tarkastelevan tutkimuksen haasteena on termien ja käsitteiden monitulkintaisuus: konflikteihin saatetaan lukea kaikki pienistä erimielisyyksistä pitkäkestoiseen ja rikosoikeudelliset tunnusmerkit täyttävään kiusaamiseen. (Vartia 2006.)

Työpaikkakiusaaminen on tilastojen mukaan yleinen ongelma suomalaisilla työpaikoilla; joka viides suomalainen on Työolobarometrin (2017) mukaan joutunut kohtaamaan työurallaan kiusaamista. 'Kiusaamisella' tarkoitetaan toimintaa, jossa työyhteisön jäseneen tai jäseniin kohdistuu jatkuvaa, toistuvaa, systemaattista ja kielteistä käyttäytymistä. Kiusaajan tavoitteeksi on tulkittu kohteen itsetunnon, maineen tai työkyvyn vahingoittaminen, ja kiusaamisen ajatellaan aiheuttavan huomattavaa psyykkistä, psykosomaattista ja sosiaalista kärsimystä. (Einarsen ym. 2011).

Kiusaaminen voi olla suoraa, kuten loukkaavia huomautuksia, nöyryyttämistä ja syyttämistä. Se voi myös olla epäsuoraa ja hienovaraisempaa, vaikeammin tunnistettavaa, esimerkiksi sosiaalista eristämistä, vaikenemista, toisen vähättelyä tai ylipäätään epätasa-arvoista kohtelua. Kiusaamisesta puhutaan prosessina, jossa huono kohtelu muuttuu kiusaamiseksi, kun toiminta muuttuu systemaattiseksi ja jatkuu pitkään. Kirjallisuudessa on kuitenkin tunnistettavissa, että työpaikkakiusaaminenkin saa usein alkunsa selvittämättömästä konfliktista tai käännekohdasta, jonka jälkeen tilanne eskaloituu ja pahenee (Einarsen ym. 2003).

Vaikka kiusaamisen on huomattu olevan usein seurausta ratkaisemattomista ristiriidoista, on havaittu myös tilanteita, joissa kiusatuksi joutunut ei ole tehnyt mitään provosoidakseen tilannetta. Kiusaaminen ja häirintä saattavat siten alkaa tyhjästä. (Vettainen, 2012).
Kiusaamisen, kuten muiden konfliktien, todetaan olevan suuressa määrin ryhmäilmiö, koko työyhteisön ongelma. Monissa tapauksissa osapuolilla on tarve hakea tukea ja hyväksyntää omille näkemyksilleen ja omalle toiminnalleen. Kiusaaminen laajenee työyhteisössä, kun molemmat osapuolet saavat lisää tukijoukkoja ja vastustajia. Kun kiusaaminen on jatkunut liian pitkään, on havaittu, että kiusatun mahdollisuudet kontrolloida tilannetta vähenevät dramaattisesti. Tutkimusten mukaan uhrin oma-aloitteisuus korjata tilannetta tai usein suositeltu avoin keskustelu voivat vain pahentaa konfliktia ja johtaa jopa kostotoimiin. Pitkään jatkuneeseen kiusaamiseen tulisikin puuttua laki- tai valtalähtöisesti eikä psykologisista lähtökohdista. Konkreettisia ratkaisuja työpaikalla ovat muun muassa kiusatun ja kiusattujen siirtäminen eri paikkoihin. (Leyman, 1996.)

Työyhteisöjen konfliktien ajatellaan kehittyvän ajan mittaan ja usein pahenevan, ellei niihin puututa ajoissa. Ensimmäisessä vaiheessa ilmaistaan erimielisyyksiä ja voidaan tunnistaa kitkaa ihmissuhteissa ja kommunikaatiossa. Toisessa vaiheessa työyhteisön tilanne on jo niin tulehtunut, että sen jäsenistä on tehty suullisia tai kirjallisia valituksia. Kolmannessa vaiheessa saatetaan nostaa virallinen syyte (Libsky \& Seeber, 2006).

Työyhteisösovittelua käytetään yleensä vasta toisessa vaiheessa, kun konflikti on näkyvä. Konfliktien moninaisuus kuitenkin vaatii harkintaa siitä, miten kulloistakin konfliktia tulkitaan ja sopiiko ratkaisukeino sekä kummallekin osapuolelle että työyhteisölle.

\section{TYÖYHTEISÖSOVITTELU PROSESSINA}

Työyhteisösovittelu prosessina koostuu yksilö- ja ryhmätapaamisista, joissa puolueeton sovittelija ohjaa keskustelua ja vuorovaikutusta. Sovittelija toimii vain niin sanottuna fasilitoijana, jolloin osapuolten aktiivisuus ja vastuunotto omasta konfliktista korostuvat. Sovittelu käynnistyy työnantajan tai osapuolten yhteydenotosta, ja koko työyhteisölle järjestetään informaatiotilaisuus prosessin kulusta sekä sovittelijan ja osapuolten rooleista.

Yhteisen tilaisuuden jälkeen kutakin osapuolta tavataan erikseen. Tapaamisissa osapuolten on 
VALTA JA ROOLIT

VAIKUTTAVAT SOVITTELUUN
JA SOVINTOON EP ̈̈SUORASTI.

mahdollista käydä läpi konfliktin taustoja ja syitä sekä siihen liittyviä tunteita. Yksilötapaamisten jälkeen osapuolet kohtaavat yhteistapaamisessa, jossa ohjatulla keskustelulla ja vuoropuhelulla hahmotetaan yhteistä ymmärrystä konfliktiin.

Prosessin tavoitteena on sopimus, johon kirjataan toimet, joilla ratkaisu saavutetaan. Perimmäisenä tavoitteena on muutos osapuolten välisessä suhteessa parempaan, ja vielä sovittelun päätyttyä muutosta seurataan keskustellen prosessin onnistumisesta sekä oppimisvaikutuksista. (Pehrman 2010, 2012.)

Vaikka työyhteisösovittelu on maailmalla tunnetumpi kuin Suomessa, meilläkin sitä on sovellettu työyhteisöihin jo 2000-luvulta lähtien ja sovittelijoiden koulutus on kasvanut maassamme räjähdysmäisesti samanaikaisesti. Sovittelutoiminta alkoi Suomessa 1980-luvulla riita- ja rikosasioiden sovittelusta, jonka sovellusalue työyhteisösovittelu on. Suomessa työyhteisösovittelun uranuurtajana pidetään sovittelusta väitöskirjan kirjoittanutta ja työyhteisösovitteluprosessin kehittänyttä Timo Pehrmania (Pehrman 2012.) Työyhteisösovittelun kehityshistoria paljastaa, että työyhteisösovittelulla on vahva perusta oikeudellisessa ajattelussa. Sovittelu pohjaa restoratiiviseen eli korjaavan oikeuden käsitteeseen, jossa rangaistuksen sijaan painotetaan vastuunottoa sekä vahinkojen korjaamista ja anteeksipyyntöä (Iivari 2010). Työyhteisönkin sovittelutilanteessa keskeisiä ovat sovittelijan puolueettomuus ja osapuolten yhteistoiminnallisuus, eli osapuolet ovat aktiivisia ratkaisun löytämisessä, eikä "ristiriitaa saa riistää sen osallisilta" (Poikela 2010).

Ristiriitatilanteiden taustalla on usein vuorovaikutusongelmia, ja sovittelun voidaankin ajatella soveltuvan parhaiten keskustelua ja vuorovaikutusta edellyttäviin tilanteisiin (Hyvönen \& Koskinen,
2010). Työyhteisösovittelu on työnantajan toimenpide turvata työyhteisön toimintakyky. Toimivan työyhteisön tunnusmerkkeinä voi tunnistaa taidon keskustella ristiriitatilanteista, mielipide-eroista ja epäonnistumisista. Oleellisinta on halu oppia ongelmien nostattamien keskusteluiden myötä. (Hyvönen \& Koskinen, 2010.)

Konflikteja on monenlaisia, ja on tärkeä tunnistaa, millaisiin tapauksiin sovittelu soveltuu. Sen käyttö edellyttää, että osapuolet ovat yrittäneet keskustella asiasta keskenään ja esimiehensä kanssa ennen prosessiin lähtöä. Sovittelu ei ole ensimmäinen ratkaisukeino. Se ei sovi myöskään tilanteisiin, joissa esimies pyrkii välttämään vastuutaan tai kun kyseessä on rikos tai rikosoikeudellisen käsittelyn vaativa asia. Sovittelulla ei liioin ole mahdollisuuksia tilanteissa, joissa toinen osapuoli on erityisen suojaton tai haavoittuvainen ja voimaton osallistuakseen prosessiin tai täysin järkähtämätön omasta osuudestaan. Sen sijaan työyhteisösovittelun menetelmänä on todettu soveltuvan erityisen hyvin rikkoutuneiden ihmissuhteiden käsittelyyn ja korjaamiseen. (Acas 2013.)

\section{SOVITTELUUN OSALLISTUVIEN NÄKÖKULMA}

Työyhteisösovittelussa sovintoon pääsy vaatii osapuolilta paljon: heidän odotetaan osallistuvan aktiivisesti sekä keskusteluun että ratkaisun löytämiseen. Vuorovaikutukseen ja tilanteen dynamiikkaan ja sitä myöten sovinnon löytämiseen vaikuttaa kuitenkin moni asia. Yksi tutkituimpia näkökulmia on vallan vaikutus sovittelun kulkuun. Vallan, valta-aseman ja roolien organisaatiossa on todettu vaikuttavan sovitteluun ja sovintoon epäsuorasti (Bollen, Euwema \& Muller, 2010). Erityisesti alaisasemassa olevat kokevat eniten epävarmuutta, ja siksi sovittelijan tulisikin antaa lisätukea juuri heille. Roolien vaikutuksesta tulisi keskustella heti prosessin alussa, ja olisi pyrittävä nostamaan esille niiden vaikutusta näkemyksiin ja odotuksiin. Oikeudenmukaisuuden tunne sovittelutilanteessa ja toisen osapuolen niin sanottu reilu ja sovitteleva käytös ja toimiva vuorovaikutus edistävät sopimukseen pääsyä. Yksinkertainen anteeksipyytäminen on todettu keskeiseksi keinoksi, jonka osapuolet kokivat oikeudenmukaiseksi ja helpottavaksi. (Nesbit ym. 2012.) 


\section{TUTKIMUKSISSA ON}

\section{LUOKITELTU TOISTAKYMMENT $\ddot{A}$}

SOVITTELIJOIDEN

TOIMINTASTRATEGIAA.

Sovittelija ohjaa osapuolia vastuunottoon rajoittamalla negatiivista kommunikointia, muun muassa syyttelyä ja vihamielisyyttä. Lisäksi hän ohjaa osapuolia miettimään, minkälaisia haasteita konfliktin mahdollinen piteneminen tuottaisi. Tunteiden ilmaisua sovittelutilanteessa pidetään merkityksellisenä: etenkin, jos osapuolet kokevat, että heidän tunteensa huomioidaan ja tunnustetaan, heidän kokemuksensa oikeudenmukaisuudesta lisääntyy (Bollen \& Euwema 2015). Sovittelijan roolia pidetään tässäkin merkittävänä, sillä sovittelija voi ohjata osapuolia tunnistamaan konfliktiin liittyvät tunteet ja kannustaa heitä muutenkin ottamaan asioihin vahvemmin tunneperspektiiviä (Jameson, Bodkter \& Linker 2010).

Sovittelukirjallisuudessa ei juuri käsitellä suoraa kritiikkiä menetelmää kohtaan, mutta aiemmista tutkimuksista voi tunnistaa menetelmän haasteita. Muun muassa osallistujien kokemuksia tutkittaessa on havaittu, että asenteet sovitteluun onnistumisesta vaihtelivat: Jotkut kokivat, että käytökseen ei sovittelun myötä tullut muutoksia, mutta siitä huolimatta sovittelu pohjusti tietä osapuolten väliselle yhteistyölle. Epäoikeudenmukaista kohtelua työpaikoillaan kokeneet alaiset tunsivat, että sovittelussa heillä oli mahdollisuus tulla kuulluksi. He kokivat voimaantumista, vaikka heidän toivomaansa epäoikeudenmukaisuutta ei suostuttu korvaamaan sovittelun lopussa. Sovittelun hyödyllisyyden kannalta keskeisin havainto oli se, että osallistujat suosittelevat sovittelua menetelmänä. (Saundry ym. 2013.)

\section{SOVITTELIJAN NÄKÖKULMA}

Sovittelun onnistumisessa sovittelijan tyylillä ja toiminnalla on suuri merkitys. Sovittelijoilla on tunnistettu erilaisia strategioita, jotka ohjaavat heidän toimintaansa ja valintojaan prosessissa (Wall \& Kressel 2015). He joutuvat punnitsemaan toimintaansa muun muassa miettiessään, miten puuttua tulehtuneeseen vuorovaikutustilanteeseen, tulisiko olla hiljaa vai ohjata tilannetta kysymyksillä tai mikä strategia parhaiten edistäisi prosessia. Päätöksenteossa toimivan toimintastrategian selkiyttäminen itselle auttaa sovittelijaa kaventamaan vaihtoehtoja ja ohjaa osaltaan vuorovaikutusta sovittelutilanteessa.

Tutkimuksissa on luokiteltu jopa toistakymmentä erilaista sovittelijoiden toimintastrategiaa, mutta ne voi tiivistää viiteen keskeiseen: neutraaliin, vuorovaikutukselliseen, transformationaaliseen, analyyttiseen ja painostavaan (Wall \& Kressel 2015). Strategia perustuu sovittelijan tavoitteeseen ja arvoihin ja määrää siten taktiikat, joilla sovittelija etenee. Neutraalissa strategiassa sovittelijan tavoitteena on vain pitää yllä osapuolten välistä vuorovaikutusta ja vaikuttaa mahdollisimman vähän tilanteeseen. Vuorovaikutuksellisessa strategiassa sovittelijalla on aktiivisempi rooli keskustelun ohjaamisessa, kun tavoitteena on parantaa osapuolten suhdetta ja pyrkiä sovintoon. Sitä voidaan tukea esimerkiksi yrittämällä rauhoittaa tulehtunutta keskustelua.

Transformationaalisessa strategiassa tavoite on voimaannuttaa osapuolia ja auttaa heitä tunnistamaan aiempaa selkeämmin tarpeensa ja toiveensa. Päätavoite ei välttämättä ole sovinto vaan tulehtuneen tilanteen lähtökohtien ja erilaisten näkökulmien ymmärtäminen. Analyyttinen strategia keskittyy itse ongelmaan, ja tavoitteena on saada tilanteeseen selkeys ja luoda sopimus. Painostavassa strategiassa, jota kutsutaan myös riskialttiiksi, pyritään muita strategioita selkeämmin vaikuttamaan ristiriitatilanteeseen haastamalla osapuolia pohtimaan asemaansa ja näkökulmiansa, ja painotetaan vahvasti sopimukseen pääsyn merkitystä. (Wall \& Kressel, 2015.)

\section{TYÖYHTEISÖSOVITTELU OPPIMISPROSESSINA}

Työyhteisösovittelu on koettu onnistuneeksi menetelmäksi, ja sitä pidetään tärkeänä keinona ratkoa työyhteisöjen konflikteja useilla toimialoilla (Bingham 2012). Sovittelusta puhutaan ennen kaikkea 
ratkaisumenetelmänä, mutta prosessin luonteen ja havaittujen seurausten myötä sitä on alettu kutsua muutos- ja oppimisprosessiksi.

\section{Miten sovittelu mahdollistaa oppimisen?}

Työyhteisösovittelu menetelmänä pyrkii parantamaan osapuolten välistä vuorovaikutusta ja sen myötä löytämään ratkaisun vallitsevaan konfliktitilanteeseen. Vaikka prosessin ydin on ongelmanratkaisussa, työyhteisösovittelussa ei keskitytä niinkään itse ongelmaan ja sen syntyyn, vaan keskiössä ovat ihminen ja osapuolten suhde. Sovitteluprosessissa restoratiiviseen teoriaan pohjautuva vaiheistus ja sisältö muodostavat yhteistoiminnallisen oppimistilanteen (Pehrman, 2012.)

Sovittelun elementit, kuten kasvokkainen kohtaaminen, demokraattisuus, tunteita painottava keskustelu, ohjaajan puolueeton rooli ja narratiivinen työote, tukevat yksilöiden muutosprosessia, jonka myötä he kehittävät tunnetaitojaan sekä kognitiivisia ja vuorovaikutustaitojaan.

Kasvokkainen kohtaaminen on menetelmän perusajatus, jolla korostetaan vastuun kantamista tilanteesta ja osapuolten aktiivista osallistumista ongelmanratkaisuun. Se haastaa ihmisen vuorovaikutustaitoja, ilmaisua ja omien näkemyksien perustelua. Sovittelusta voidaan puhua voimaannuttavana prosessina, jossa osapuolia autetaan tunnistamaan aiempaa selkeämmin omia tarpeitaan ja toiveitaan ja kommunikoimaan niistä yhä avoimemmin (Wall \& Kressel 2015).

Työyhteisösovitteluprosessissa osapuolia ohjataan ilmaisemaan, sanoittamaan ja tunnistamaan tunteitaan, jolloin tietoisuus niistä kasvaa ja keinot nimetä ja ilmaista tunteita kehittyvät (Jameson ym. 2010). Sovittelussa tiedostetaan, että tunteet ovat monen konfliktin pohjalla, ja keskustelussa pyritään ohjaamaan osapuolia ymmärtämään toisen näkökulmaa. Näin ymmärrys toisen kokemasta kasvaa ja auttaa osapuolia tunnistamaan konfliktiin liittyvät tunteet. Tunneperspektiivin ottaminen mukaan on siis keino tukea yksilöiden oppimista konfliktien käsittelykeinoja ja tunteiden hallintaaja tunnistamista haastavissa tilanteissa. (Jameson ym. 2010.)

Sovittelun yksi erityispiirre on sovittelijan puolueeton ja fasilitoiva rooli, jonka tavoite on tukea osapuolia toimimaan aiempaa itsenäisemmin. Sovittelijan roolissa olennaisinta on tukea vuorovaikutuksen demokraattisuutta, jotta kaikki saavat äänensä kuuluville. Lisäksi sovittelija ohjaa keskustelun sisältöä, jotta se pysyisi ihmiskeskeisenä, sillä osapuolten on havaittu herkästi kääntävän keskustelun työtehtäviin. Tällainen niin sanottu järkeistäminen estää pahimmillaan avoimen keskustelun, ja sitä voidaan pitää eräänlaisena defenssinä, jossa halutaankin tosi asiassa vältellä ihmisten välisen vuorovaikutuksen puutteesta johtuvia haasteita (Kaivola 2003).

Oppimisen näkökulmasta fasilitatiivinen tyyli on merkityksellinen. Siinä sovittelija ei ratkaise osallistujien puolesta ongelmaa eikä sen käsittely jää pinnalliseksi, kun osallistujat itse joutuvat tunnistamaan ja tuomaan omia tunteitaan ja ajatuksiaan esille. Oppiminen eli käyttäytymisen muutos on mahdollista, kun osapuolilla on alusta asti vahva rooli.

Tarinallisuudella on merkittävä rooli oppimisessa. Sovitteluvaiheessa hyödynnetään narratiivista työotetta eli menetelmää, jossa kertoja tuottaa omaa elämäntarinaansa tai tarinaa tapahtuneesta elämänjaksosta omin sanoin. Narratiivisuuden taustalla on ajatus, että tarinankerronta on osa yksilön identiteettityötä, jossa samalla sekä luodaan ymmärrystä menneestä että selitetään itselle tapahtumien kulkua ja rakennetaan tulevaa. (White 2007.) Narratiivisuudella pyritään tukemaan osapuolten ongelmankäsittelyä ja syvällistä keskustelua, ja sillä voi siten olla terapeuttisiakin vaikutuksia. Tarinallisuus kehittää yksilöiden ilmaisua, mutta myös asioiden ymmärrys paranee, kun yksilö kykenee vaihtamaan näkökulmaa ja pohtimaan tapahtumia eri perspektiiveistä.

\section{Mitä osapuolet voivat oppia sovittelussa?}

Työyhteisösovitteluun otetaan mukaan koko työyhteisö, jolloin sen ajatellaan prosessina kehittävän koko työyhteisöä (kuvio 1). Kirjallisuudesta tunnistetaan, että sovittelu ei kehitä vain yksilöä vaan koko yhteisöä ja organisaatiota. Sovittelutilanne perustuu vuorovaikutukseen ja yhteistoiminnallisuuteen, joten ensisijaisesti oppimista voidaan pitää ihmissuhde- ja kommunikointitaitojen kehittymisenä. Esimiesten sovittelutaitoja tarkastellut Poitras kollegoineen (2015) totesi, 


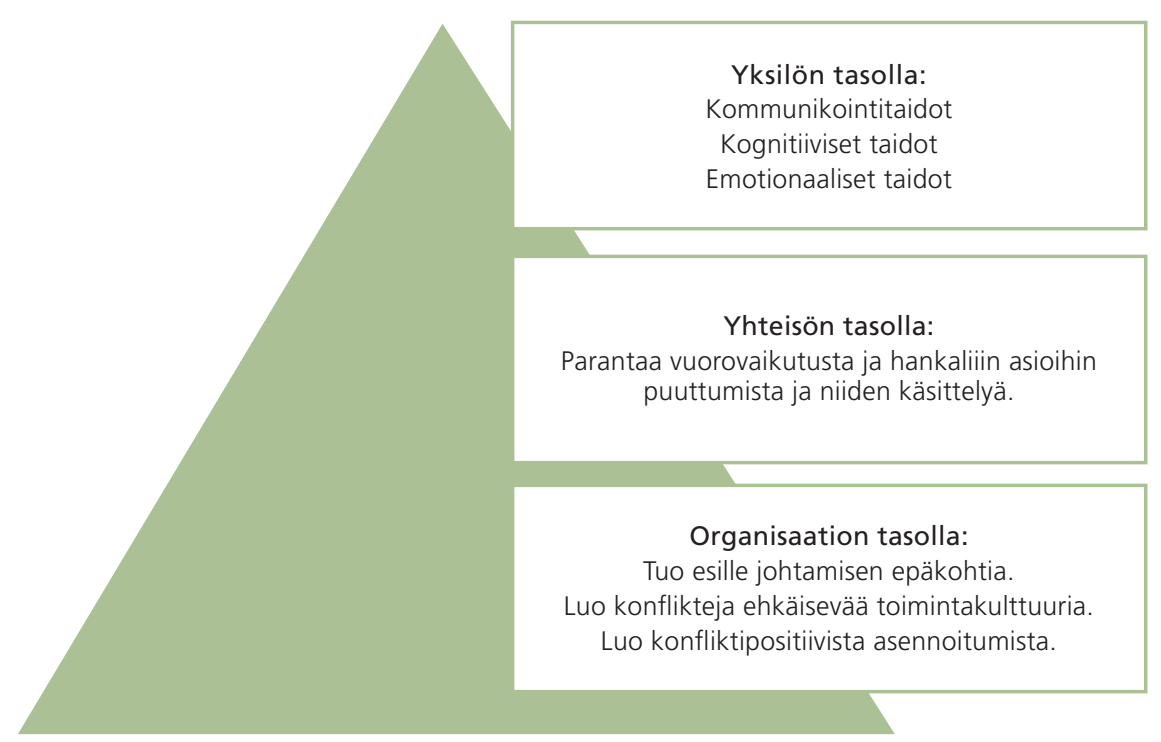

Kuvio 1. Työyhteisösovittelussa oppimista tapahtuu organisaation joka tasolla.

että taidot koostuvat emotionaalisista, kognitiivisista ja vuorovaikutustaidoista.

Sovittelun menetelmiin kuuluu osapuolten haastaminen ajattelemaan erilaisista näkökulmista ja punnitsemaan omia piileviä asenteita, minkä myötä emotionaaliset taidot kehittyvät. Tunnetaitoihin voidaan lukea toisten tunteiden huomioiminen ja omien tunteiden ilmaisu. Kognitiivisista taidoista puhutaan taas, kun yksilö oppii laajentamaan ajatteluaan minäperspektiivistä ja osaa ottaa huomioon toisenkin näkökulman. Kommunikoinnin näkökulmasta se voi olla ratkaisukeskeisen tyylin kehittämistä ja erilaisten näkökulmien sovittelemista. Sovittelija ohjaa jatkuvasti osapuolia ottamaan vastuuta, mutta rajoittaa ja puuttuu keskusteluun, jos tilanteet täyttyvät syyttelystä tai vihamielisyydestä. (Nesbit ym. 2012.) Prosessi opettaa myönteistä ja rakentavaa kommunikointia ja viestintätyyliä läpi tapaamisten.

Vaikka konfliktin ytimessä on usein kaksi ihmistä, sovittelussa ajatellaan, että konflikti on koko työyhteisön tukema. Työyhteisösovittelussa usein osallistetaan ja otetaan huomioon koko työyhteisö, jolloin menetelmä voi parhaimmillaan kehittää työyhteisöä ehkäisemään, käsittelemään ja ratkaisemaan konflikteja. Työyhteisön tasolla opitaan, että konflikteihin tulee puuttua ajoissa ja rohkeasti, ja parhaimmillaan ne toimivat oppimiskokemuksina. Jättämällä konfliktit selvittämättä luodaan jatkumo uusille konflikteille ja saatetaan aiheuttaa pitkällä tähtäimellä ongelmia työyhteisöissä. Puhumattomuuden myötä ei tulla tietoisiksi vahingollisista toimintatavoista, mikä voi johtaa siihen, että vältellään ristiriitojen ilmaisua, ja koko organisaation vuorovaikutusilmapiiri vaurioituu.

Pehrmanin $(2010 ; 2012)$ mukaan kyseessä voi olla niin sanottu puhumattomuuden kehä, joka samanaikaisesti sekä pitää yllä että vahvistaa haitallisia toimintatapoja organisaatiossa. Työyhteisösovittelun avulla tällainen toimintakulttuuri voidaan katkaista ja työyhteisöä herättää uudenlaiseen ajatteluun ja ajatusten ilmaisuun. Sovittelu voi muuttaa asennoitumista uuden oppimiseen ja nimenomaan konflikteista oppimiseen. Voidaan puhua konfliktipositiivisesta organisaatiosta. Sen kulttuuri perustuu toimintamalliin, jossa haetaan ratkaisua, kohdataan ongelma ja otetaan vastuu. 
TYÖYHTEISÖSOVITTELULLA TAVOITELLAAN KAUASKANTOISEMPAA MUUTOSTA

Työyhteisösovittelu on ensisijaisesti konfliktinratkaisumenetelmä, mutta restoratiiviseen teoriaan pohjaava prosessi voi olla kehittävä. Konfliktin ytimessä osapuolet kehittävät sekä tunne-, ajattelu- että kommunikointitaitojaan. Työyhteisösovitteluprosessiin lähteminen viestii lisäksi työyhteisölle siitä, että työntekijöiden hyvinvointia arvostetaan tukemalla heitä käsittelemään ja ratkaisemaan konflikteja. Vaikka konflikti olisi vain kahden ihmisen välinen, se heijastuu koko yhteisöön, ja siten sen kerrannaisvaikutukset ovat usein mittavat. Organisaatio voi konfliktin kohdatessaan vältellä, vähätellä tai pakottaa osapuolia ratkaisuun, mutta sovitteluun perustuvassa ongelmanratkaisussa keskitytään henkiseen kehittymiseen: asenteiden, tunteiden ja vuorovaikutuksen kehittämiseen ja siten kauaskantoisten muutosten aikaansaamiseen.

Työntekijöiden väliset konfliktit ovat monisyisiä, mutta niiden teemat kietoutuvat usein johtamiseen, esimiestyöhön ja työpaikan toimintakulttuuriin, jolloin sovittelua tulisikin pitää osaamisen kehittämisen välineenä. Organisaatiomuutoksen on todettu tapahtuvan vain muuttamalla jokapäiväisiä keskusteluja ja suositellaankin, että organisaatiota kehittäessä on hyvä käyttää interventioita, joilla tuodaan tietoisuuteen organisaatiossa vallitsevat monet todellisuudet, sekä luomalla uusia todellisuuksia vuoropuhelun avulla. (Bushe \& Marshak 2008.) Työyhteisösovittelu haastaa juuri tähän: ohjatun dialogin avulla kohti yhteistä ymmärrystä. Siinä missä työyhteisön osaamisen kehittämistä usein pidetään pelkästään kouluttautumisena, työyhteisön haasteisiin puuttuminen voi olla koko yhteisölle oppimiskokemus.

Vaikka sovittelusta menetelmänä on laajasti hyviä kokemuksia ja sitä on sovellettu riidanratkaisumenetelmänä monilla aloilla ja monenlaisiin konfliktityyppeihin (Bennet 2013), konfliktit ovat monisyisiä. Menetelmää valittaessa tuleekin pohtia tarkasti, onko sovittelu sopiva ratkaisumalli. Kaikki konfliktit eivät sovellu työyhteisösovitteluun, ja johdolla tulee olla vahva näkemys siitä, onko esimerkiksi rikoksen tunnusmerkit ylitetty, kuten häirinnässä tai ahdistelussa.
Erityisesti kiusaamistapauksissa on pohdittava vakavasti, tarjoaako työyhteisösovittelu tilaisuuden asioiden ratkaisemiseen. Onko tapauksessa mahdollisuuksia vielä avoimeen keskusteluun? Ovatko osapuolet henkisesti siinä kunnossa, että sovitteluprosessi on mahdollinen? Aiemman tutkimuksen mukaan vakavissa kiusaamistapauksissa osapuolten tasavertainen kohtaaminen harvoin onnistuu ja pitkittyneissä tilanteissa on todettu, että ainoastaan valtaan ja lakiin nojautuen voidaan saada muutosta tilanteeseen (Leyman 1996).

Sovittelun voidaankin ajatella toimivan parhaillaan siinä vaiheessa, kun organisaatio on selvittänyt kiusaamisen alkulähteet ja ymmärtää, mitkä asiat ovat ajaneet tilanteen eskaloitumiseen. Tällöin sovittelussa voidaan keskittyä osapuolten senhetkiseen käyttäytymiseen ja suhteeseen, mikä mahdollistaa osapuolten suhteen rakentamisen uudelleen. Ellei ymmärretä taustatekijöitä, sovittelun mahdollisuudet vaikuttaa ehkäisevästi tuleviin konflikteihin ovat vähäisiä, ja pahimmillaan kiusaaminen vain jatkuu. Erityisesti kiusaamistapauksissa sovittelijoiden tulisi työskennellä läheisesti organisaation henkilöstöasioista vastaavien, psykologien ja muiden konfliktin asiantuntijoiden kanssa luodakseen mahdollisimman kestävän ratkaisun tilanteeseen. (Jenkins 2011.)

Työyhteisösovitteluprosessin erityisyys muihin ratkaisumalleihin verrattuna on siinä, että konfliktia ei irroteta kontekstistaan, vaan mukaan otetaan koko työyhteisö ja ymmärretään, että työpaikan dynamiikka ja toimintatavat rakentuvat yhteisöllisesti. Konfliktien jäljet eivät kuitenkaan ole siivottavissa organisaatiosta yhdellä käsittelykerralla, vaan muutos vaatii aikaa. Hyvinvoivaa työyhteisöä ja ilmapiiriä ylläpidettäessä merkityksellistä on se, miten konflikteja käsitellään, pyritään ehkäisemään ja miten niihin suhtaudutaan organisaation arjessa.

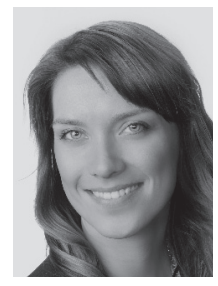

JENNI KANTOLA

FT, yliopisto-opettaja

Vaasan yliopiston johtamisen yksikkö Kokkolan yliopistokeskus Chydenius 
Acas (2013). Mediation: an approach to resolving workplace issues. ACAS report, February 2013. https:// www.acas.org.uk/media/949/Mediation-An-approachto-resolving-workplace-issues/pdf/Mediation-anapproach-to-resolving-workplace-issues.pdf.

Bennett, T. (2013). Workplace mediation and the empowerment of disputants: Rhetoric or reality? Industrial Relations Journal 44(2), 189-209.

Bingham, L. B. (2012). Transformative mediation at the United States postal service. Negotiation and Conflict Management Research 5(4), 354-366.

Bollen, K. \& Euwema, M. (2013). Workplace Mediation: An Underdeveloped Research Area. Negotiation Journal 29(3), 329-353.

Bushe, G. \& Marshak, R. (2009). Revisioning Organization Development: Diagnostic and Dialogic Premises and Patterns of Practice. The Journal of Applied Behavioral Science 45(3), 348-368.

Coleman, P. (2015). Putting the peaces together: A situated model of mediation. International Journal of Conflict Management 26(2), 145-171.

Einarsen, S. \& Hoel, H. \& Zapf, D. \& Cooper, G. (2011). The Concept of Bullying and Harassment at Work: The European Tradition. Teoksessa Einarsen, S., Hoel, H., Zapf, D. \& Cooper, C. L. (toim.) Bullying and Harassment in the Workplace. 2. painos. Boca Raton, FL: CRC Press, cop, 3-39

Gallo, G. (2013). Conflict Theory, Complexity and Systems Approach. Systems Research and Behavioral Science, System Research 30, 156-175.

Hyvönen, A. \& Koskinen, S. (2010). Sovittelu työelämän ristiriitatilanteissa. Teoksessa Poikela, E., (toim.) Sovittelu: Ristiriitojen kohtaamisesta konfliktien hallintaan. Jyväskylä: PS-kustannus, 157-172.

livari, J. (2010). Oikeutta oikeuden varjossa restoratiivisen oikeuden tausta ja kehitys. Teoksessa: Poikela, Esa (toim.) Sovittelu - Ristiriitojen kohtaamisesta konfliktien hallintaan. Jyväskylä: PSkustannus.

Ikonen-Varila, M. (1994). Työyhteisön ristiriitatilanteet moraalitutkimuksen näkökulmasta. Helsinki: Helsingin yliopiston Kasvatustieteen laitos.

Jameson, J. \& Bodtker, A. \& Linker, T. (2010). Facilitating conflict transformation: Mediator strategies for eliciting emotional communication in a workplace conflict. Negotiation Journal, January 2010, 25-48.

Jehn, K. (1997). A qualitative analysis of conflict types and dimensions in organizationa groups. Administrative Science Quarterly 42(3), 530-558.

Jenkins, M. (2011). Practice note: Is mediation suitable for complaints of workplace bullying? Conflict Resolution Quarterly 29(1), 25.
Järvinen, I. \& Luhtaniemi, T. (2014). Ratkaisukeskeinen työyhteisösovittelu. Helsinki: Työterveyslaitos.

Leymann, H. (1996). The Content and Development of Mobbing at Work. European Journal of Work and Organizational Psychology 5(2), 165-184.

Nesbit, R. \& Nabatcji, T. \& Blomgren Bingham, L. (2012). Employees, Supervisors, and Workplace Mediation. Review of Public Personnel Administration 32(3), 260-287.

Pehrman, T. (2010). Konfliktien synty ja sovittelu työyhteisössä. Teoksessa E. Poikela (toim.) Sovittelu. Ristiriitojen kohtaamisesta konfliktien hallintaan. Jyväskylä: PS-kustannus.

Pehrman, T. (2012). Paremmin puhumalla: restoratiivinen sovittelu työyhteisössä. Acta Universitatis Lapposiensis 212. Lapin yliopistokustannus.

Poikela, E. (2010). Miksi ja mitä sovitellaan? Teoksessa: E. Poikela (toim.) Sovittelu. Ristiriitojen kohtaamisesta konfliktien hallintaan. Jyväskylä: PS-kustannus.

Poitras, J. \& Le Tareau, A. (2009). Quantifying the Quality of Mediation Agreements. Negotiation and Conflict Management Research 2(4), 363-380.

Rahim, M. (2015). Managing Conflict in Organizations. New Jersey: Transaction Publishers.

Rouhiainen-Neunhäuserer, M. (2009). Johtajan vuorovaikutusosaaminen ja sen kehittyminen: johtamisen viestintähaasteet tietoperustaisessa organisaatiossa. Väitöskirja. Jyväskylän yliopisto.

Saundry, R. \& McArdle, L. \& Thomas, P. (2013). Reframing workplace relations? Conflict resolution and mediation in a primary care trust. Work, Employment \& Society 27(2), 213-231.

Saundry, R. \& Bennett, A. \& Joseph, W. \& Wibberley, G. (013) Workplace mediation: the participant experience. Acas research papers. ORCID: 00000002 78278227.

Työolobarometri 2017. Ennakkotiedot. Työ- ja elinkeinoministeriön julkaisuja. Työelämä 3/2018.

Vettainen, H. (2010). Epäasiallinen käyttäytyminen ja häirintä työpaikoilla - Tehyn toimintaohjeita ristiriitatilanteiden ratkaisuun. Helsinki: Tehy.

Wall, J. \& Dunne, T. (2012). Mediation Research: A Current Review. Negotiation Journal (April), 217-244.

Wall, J. \& Callister, R. (1995). Conflicts and Its Management. Journal of Management 21(3), 515-558.

Wall, J. \& Kressel, K. (2012). Research on mediator style: A summary and some research suggestions. Negotiation and Conflict Management Research 5(4), 403-421.

White, M. (2007). Karttoja Narratiiviseen Työskentelyyn. Keuruu: Gummerus Kirjapaino Oy. 